\title{
Lingual Domination in Tourism Discourse: A CDA Study
}

\author{
${ }^{1}$ I Nengah Laba, ${ }^{2}$ I Ketut Riana, ${ }^{3}$ Made Budiarsa, ${ }^{4}$ I Wayan Pastika \\ 1. bahagia@inengahlaba.com Sekolah Tinggi Pariwisata Bali Internasional \\ 2. k.riana@gmail.com Faculty of Arts, Udayana University \\ 3. made_budiarsa@yahoo.com Faculty of Arts, Udayana University \\ 4.wayanpastika@unud.ac.id Faculty of Arts, Udayana University
}

\begin{abstract}
This study examines tourism discourse in the national print media to answer a research question of how lingual domination is presented in the tourism discourse. This study uses a method of qualitative research methodology. The approach in this study is a phenomenological approach using the phenomenon of the use of language in national printed media. The grand theories used in this research is the theory of critical discourse analysis proposed by van Leeuwen $(2005$; 2008) and lingual domination by Burton $(2008 ; 2012)$ with a supporting theory of Critical Discourse Analysis proposed by Fairclough (1989; 1995). The research results of this study indicate that lingual domination in tourism discourse show social effects on 1) attitude change; 2) cognitive change; 3) collective reactions; 4) personal reactions; 5) agenda setting; 6) socialization; 7) social control; 8 ) defining reality; and 9) endorsement of dominant ideology.
\end{abstract}

Keywords: critical discourse, lingual domination, and tourism

\section{Introduction}

Language has a vital role in communication and social interaction in the community. The tourism development affects the language dynamically and this can be seen from the intersection between languages in tourism which has become a central phenomenon in post-modern society (cf., Fox, 2008: 13-15). This evident can be seen from the fact that the tourism industry can enrich vocabulary and terms in the Indonesian language that is closely related to tourism, such as vocabulary used in restaurants and by waiters. It proves that the growth of tourism does not only affect the economic, socio-cultural and natural environment, but also the use of language. As an integrated system of representation, language is also a core medium for the tourism community and media institutions for producing a message that is revealed in the text and discourses. In relation to this, mass media are likely a struggle area of any interest that can be seen from the implementation of various strategies which arise from lingual domination. This means in presenting information, mass media will not be separated from the multiple conflicts of interest that are often caused by the various needs to instill a certain ideology. The media are also used as 
a space to show up and dominate the social discourse. According to van Leeuwen and Machin (2007: 60-61), the discourse can also transform social praxis through various elements and contexts of interest.

The text in printed media as a form of mass media is the result of a discourse process that contains the values of representation, domination and ideology as a broadcaster, and the printed media has often not been neutral in explaining social reality. That is, the media will include perspectives from their point of views in explaining social reality. To find out how the printed media involves its views, the use of language as an important element is to be observed. With regard to this, lingual constructions in the form of words, phrases, sentences or specific expressions on tourism discourse have to be analyzed and this option is not a coincidence and not too arbitrary. It is assumed that the choice has been made to have a certain perspective, a certain agenda and ideology, for example, in the sentence: "alih fungsi lahan produktif untuk pariwisata sudah pada tingkat mengkhawatirkan". This sentence shows that there is a land conversion by displaying the objects of tourism without indicating who is responsible for the land conversion.

Discourse with capitalism or socialism ideology will produce a discourse with their characters. From this explanation, we can understand that critical discourse analysis will put the language in opening system based on their contexts. The analysis will always reveal how the text is produced and reproduced as a result of an interest and subsequently used as an instrument of domination in creating a particular ideology. 
The relationship among media, discourse and ideology can be described as follows.

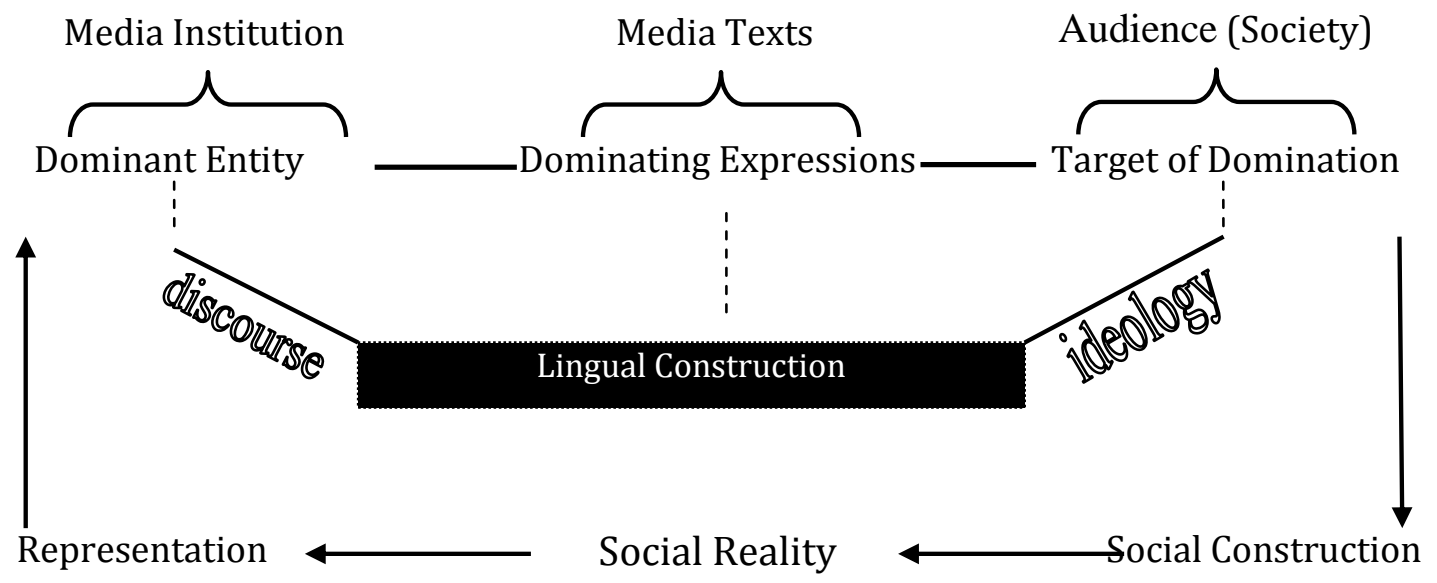

\section{Chart 1.1}

\section{The Relationship among Media, Discourse and Ideology}

\section{(Source: Burton, 2012:75 modified by the researcher)}

The chart above describes that the representation of the interests of a person or group requires media institutions and all instrument operations in order to open up the space in the discourse of domination through various lingual constructions as an effort to inculcate the ideology of either real or veiled to the public (community). Ideology will show the effects related to the attitudes and behavior of the audience as the cause of social construction that will affect social reality and need a space to represent itself. In this context, critical discourse analysis can be used as a framework to explore the representations and forms of domination in social life and the meaning can be seen through the lingual construction which has appeared in various strategies of discourse used (van Leeuwen, 2005: 95). In connection with these issues, further study is needed to explore the forms of lingual domination. Therefore, research problem is formulated as "How is lingual domination presented in tourism discourse on the national print media?"

\section{Literature Review and Theoretical Framework}




\subsection{Literature review}

The main focus in conducting literature review is on how the researcher acquired the information in form of theories used in this research, data, methodology, findings with their strengths and weaknesses based on the concepts and approaches to get the relevance of this research. The literature review which is described in this study consists of three parts, namely: (1) textbooks that contribute to the framework in this study; (2) similar previous researches with relevant methodology and theoretical frameworks that support this study; and (3) the object of research, that is tourism discourse.

Ling Ip (2008) entitled Analyzing Tourism Discourse: A Case Study of Hongkong Travel Brochure. This study reviewed about parts of tourism discourse in destination brochures in Hongkong. Ling Ip used a multimodal analysis method in reviewing the language used in a brochure in explaining many tourism destinations that are managed by Splendid Tours\& Travel Limited as a part of The Hongkong Tourism Board. Ling Ip also reviewed the language used from micro to macro linguistics and the visual elements in those brochures and also the factors effecting interpretation of tourism discourse; the seventh study by Thurlow and Jaworski (2011) entitled Tourism Discourse: Language and Banal Globalization. This study explained about 1) tourism discourse in globalization, 2) the role of language and communication in tourism, 3) an understanding of the language in globalization or a post industrial era (especially in tourism), 4) the circulation of linguistics material such as genre and language style and 5) how the local language are commodificated in tourism communication as stated by Bourdieu (1991) and Irvine (1989). The study by Thurlow and Jaworski on Tourism Discourse: Languages and Banal Globalization inspiring the researcher that tourism theme can be reviewed by linguistics approach. Research carried out by Bestari, Artawan and Yasa (2014) entitled " Pemberitahuan Gubernur Bali, Mangku Pastika, in Balipost newspaper: Analisis Eksklusi- Insklusi Theo van Leeuwen. This research used a descriptive qualitative approach to describe an exclusion and inclusion strategy in Bali Post about Gubernur Bali, Mangku Pastika. The objects used in this research were 22 data in form of sentences structure from 19 September 2011 to 21 Juli 2012 which used discourse analysis approach using the van Leuween model. Kheirabadi and Moghaddam (2012) did a research of linguistics on international mass media using discourse analysis approach entitled "The Linguistic Representation of Iranian and Western Actors of 
Iran's Nuclear Program in International Media: A CDA Study. This research used discourse analysis approach of Fairclough (2001) and van Leeuwen (2008) models about social actors to review news and international articles that tell about the Iranian nuclear program. The source of data in this research taken from 50 news and articles of the international media including Agance France Press, Bloomberd, The Wall Street Journal, The Associated Press, The New York Times, The Washington Post, Reuters, and BBC News published in November - December 2010. In this study, Khierabadi and Moghhadam review the neutralization of printed media in giving information about the Iranian nuclear program from a linguistics point of view with discourse analysis to explore the socio semantics in reporting news. The result of study showed that international mass media were not neutral in giving information about the Iranian nuclear program.

To avoid misunderstandings or different perceptions toward research focus, there are some basic concepts used in this research. The concepts are lingual domination, tourism discourse, and national printed media. Burton (2008) stated that mass media through various lingual dominances in forms of the structure used and the form of sentences will have the power to create the knowledge and perception of society about the world. In this context, the use of language is seen to be not neutral because it is showed that there is domination in society which implied certain ideologies. In short, lingual domination in this research is all structures and sentences used on national printed media which showed domination by a certain party to other parties.

Tourism can be defined as a service industry of transportation, hospitality, housing, hospitality service, food and beverages that relates to other services such as bank, insurance and security. Hallet and Weinger (2009:11) explained the relationship between discourse and tourism in linguistics. They stated that the discourse of tourism is a discourse of identity construction, promotion, recognition, and acceptance. It is a discourse created through the creation and manipulation of linguistic and visual texts. Although these texts are specific their locale, they share common goals are transparent through the work of discourse analysis. Those goals involve both producer and audience. Based on Halet and Weinger (2009) explanations, the tourism discourse in this study is defined as written texts which describe the activities relating to tourism and published in the national printed media. Nurudin (2009:36) stated that mass communication 
has provided a new revolution in the era of the information period that is able to create community characters. Therefore, the high dependence of information as the means to deliver messages will be able to establish the existence of a society. In mass media, audiences are often called or mentioned directly in the text. That approach is a process of how the text communicates with the audiences and how the audiences are positioned by the text. In this research, the printed media is defined as a means of mass media which is printed and published continuously like newspapers and magazines. Those printed media are Bali Post, Nusa Bali and Kompas.

\subsection{Theoretical Framework}

To analyze and describe the phenomena in this study explicitly, the researcher used some relevant theories. Those theories are 1) critical discourse analysis theory; 2) critical discourse analysis theory of van Leeuwen model with exclusion and inclusion strategy approach; 2) lingual domination theory by Burton (2008) who said mass media through lingual displayed has power to do construction and reconstruction of social reality. According to Mayr (2008), a discourse is started from social analysis by Foucault (1977), lead to critical linguistics by Fowler, et al (1979), and critical discourse analysis pioneered by Van Dijk (1990). Moreover, Mayr explained the definition of discourse can be seen from two different perspectives, which are structuralism and functionalism. The structuralism views the discourse as the use of language especially of clauses and sentences that focus on how the structure of a text is framed as a whole and reflected in cohesion and coherence (cf. Halliday and Hasan, 1987:21-23; Halliday, 1994:129). In this context, structuralism does not focus on social aspects which provide information about how people use and interpret the language. Meanwhile, the functionalist views discourse as a form of "language in use" which cannot be separated from the purpose and function of language as a communication tool in social praxis.

In critical discourse analysis, discourse is not merely seen as language study. Critical discourse analysis uses textual language to be analyzed. The result of analysis is not only to gain an overview of language aspects, but also relate to the social aspect. Regarding the discourse, van Leeuwen (2005:94) said that:

"The term" discourse "is often used to denote an extended stretch of connected speech or writing, $a^{\prime \prime}$ text "."Discourse analysis" then means "the analysis of an extended text, or type of text". " 
Furthermore, van Leeuwen explained that the discourse is often used to express speech and writing that is related to each other and called text. So, the theory of discourse analysis model of van Leeuwen reveals the scope of the text or certain types of text. Leeuwen introduced the model of discourse analysis to detect and investigate the process person or group within a discourse to be marginal. In that context, there is a relationship between discourse and power in which the forms of representation and domination become an integral part of social life. Discourse on the national printed media is always linked with social practice.

\section{Research Methodology}

The model used to analyze the lingual domination in tourism discourse is descriptive qualitative research with critical discourse analysis approach as the main part to explore text production. The method used in this study was descriptive qualitative research using systematic writing of theory and then data observation continued with triangulation (Bungin, 2008: 23-24). This study contains excerpts such data to illustrate the presentation of the report. Because it is related to lexical use and linguistic aspects in tourism discourse, the description is very important to get a clear understanding of the problem discussed above. Corpus linguistics in this study is in form of lexical data, phrase, grammar and textual phenomena by language user on printed media in order to reveal tourism discourse, so lingual domination in the text can be further analyzed (cf. Baker, 2010: 93 -95; Bednarek, 2006: 5-6). Litosselti, et al. (2010: 146) states that researchers themselves can be the main instrument in a variety of qualitative research to collect data, analyze the results and report findings. After the data has been collected, it is classified and assisted by advanced technique namely technique noted. Technique noted in this study is used as a technique to record the various forms of relevant data in this study. This technique will be supported with transcription and transliteration to obtain valid data (Mahsun, 1995; 2005).

\section{Discussion}

Lingual domination refers to a variety of construction that appears in tourism discourse in media that showed the domination for the audience to its effect on society. Burton (2010: 13) states that the meaning of a discourse is about values, beliefs and the dominance of their representation. In line with this, Faiclough (1995) argues that language and its relation to social 
community context can lead to a non-symmetrical relationship. This means that the practice of discourse through text creates power relationships imbalance between the social classes, men and women, the majority and minority groups where the difference was represented in social practices. This is the role of discourse analysis to explore the social practice in tourism discourse. The conception of inoculation theory and cultivation theory in media studies stating that the submission of emphasis messages repeatedly, and the degree of correlation between the delivery of messages by the media to the public could lead to a change of attitude towards a particular issue (Burton, 2002: 259). Referring to the lingual domination theory put forward by Burton (2008), lingual text on the media can be used as an instrument of domination by some effect on them, These effects include 1) a change in attitude; 2) cognitive changes; 3) moral panic; 4) the emotional / personal reaction; 5) agenda setting; 6) socialization; 7) social control; 8) defines reality; and 9) smiles against the dominant ideology. Exposure to the effects of domination that creep into the discourse of tourism through the lingual aspect in the national printed media described as follows.

Data (1)

Mereka sering menuai keluhan tamu asing," kata Semarajaya, salah satu warga setempat, senin (8/7) kemarin. Pria yang juga pengurus subak ini mengaku kerusakan jalan di Jatiluwih sudah berlangsung lama. Namun, belum ada proyek perbaikan yang maksimal. (BP, 9/7/2013)

"They are often drawn complaints of foreign guests, "said Semarajaya, one local resident, Monday (8/7) yesterday. He who is also a board member, admitted that the road along Subak Jatiluwih have been damaged for long time. However, improvement hasn't been made maximally. (BP, 09/07/2013)"

The structure of the sentence, "Pria yang juga pengurus subak ini mengaku kerusakan jalan di Jatiluwih sudah berlangsung lama ", shows the effect of cognitive change as indicated by the expression Semarajaya, a resident in Jatiluwih frequently received complaints from foreign guests due to damaged roads. Cognitive changes of the residents around Jatiluwih arising from its impact on their minds after seeing and observing the condition of roads without any maximum improvement made. This is reinforced by argumentative sentence, Namun, belum ada proyek perbaikan yang maksimal (However, improvement hasn't been made maximally). 
Construction syntactic lexicon liaison with contrastive lexicon of namun (but) further strengthens the cognitive change.

Data (2)

"Padahal, banyak aktivitas menarik di Bali, salah satunya sport," ujarnya. Wisatawan di Bali hanya tinggal di hotel. Jadi yang dijadikan destinasi adalah hotelnya, padahal hotel hanya sebagai fasilitas menginap. (BP, 149/2013)

"In fact, there are a lot of attracting activities in Bali. One of the is sport," he said. In Bali, tourists just stay at the hotel. So, the destination is the hotel itself. But, it is only a facility to stay in. (BP, 14/9/2013)"

The cognitive understanding of the society in the context of tourism discourse is mainly on hotel. This is reflected in the structure of the sentence, "Jadi yang dijadikan destinasi adalah hotelnya, padahal hotel hanya sebagai fasilitas menginap" (So, the destination is the hotel itself. But, it is only a facility to stay in). Cognitive changes over the definition of tourism that is so complex narrowed the realm of a hotel. Other tourist activities such as sport events have no much attention. The lexicon of hotel on the data implies that discourse tourism is narrowed down only as a hotel business. The process of cognition is the stigma of a link between tourism needs to be distinguished that the hotel is only a facility of tourism activities and not tourism destinations.

\section{Conclusion}

From the discussion above, it can be concluded various forms of lingual domination reflected from the elements of linguistics features including lexicon, phrase and certain structures. Lingual domination refers to a variety of construction that appears in tourism discourse in media that showed the domination for the audience to its effect on society. Burton (2010: 13) states that the meaning of a discourse is about values, beliefs and the dominance of

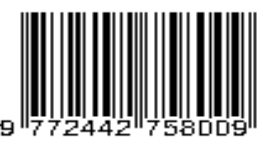


July 2017 Vol. 11. No. 2

Support DOAJ Directory Open Access Journal

http://ojs.unud.ac.id/index.php/eol

ISSN: 2442-7586 (Online)

Page: 93-104

ISSN: 2541-5514 (Print)

their representation in a discourse so communication in a discourse is also a means to put an ideology. Linguistics study with a tourism theme in the perspective of critical discourse analysis approach through critical paradigm is also associated with other social sciences. 


\section{References}

Baker, P. 2010. Corpus Methods in Linguistics. Dalam Litosseliti, L (ed). Research Methods in Linguistics. London: Continuum International Publishing Group.

Barker, C. and Galasinski, D. 2001. Cultural Studies and Discourse Analysis: A Dialogue on Language and Identity. London : SAGE Publications Ltd.

Benarek, D. 2006. Evaluation in Media discourse: Analysis of a Newspaper Corpus. London: Continuum.

Bestari, T.R., Artawan, G., Yasa, I N. 2014. "Pemberitaan Gubernur Bali, Mangku Pastika, dalam Surat Kabar Bali Post: Analisis Strategi Eksklusi-Inklusi Theo van Leeuwen. eJournal Universitas Pendidikan Ganesha, JPBSI, Vol: 2 No. 1 Tahun 2014.

Bungin, H.M.B. 2008. Penelitian Kualitatif. Jakarta: Prenada Media Group

Burton, G. 2002. More Than Meets the Eye. An Introduction to Media Studies. Third Edition. London: Oxford Univeristy Press, Inc

Burton, G. 2008. Yang Tersembunyi di Balik Media. Pengantar kepada Kajian Media. (Alfathri Adlin, Pentj.) Yogyakarta: Jalasutra.

Burton, G. 2010. Media \& Society. 2nd Edition. New York: Open University Press.

Burton, G. 2012. Media dan Budaya Populer. (Hodder Arnold, Pentj.) Yogyakarta: Jalasutra.

Fairclough, N. 1995. Critical Discourse Analysis. The Critical Study of Language. HarlowEssex: Longman Group Limited.

Fox, R. 2008. "English in Tourism: A Sociolinguistic Perspective", Tourism and Hospitality Management, An International Journal of Multidisiplinary Research for South-Eastern Europe, Vol. 12, No. 1, 2008.

Hallet, Richard W. and Weinger, J.K. 2009. Official Tourism Websites: A Discourse Analytic Perspective. Chicago: IL.

Halliday, M.A.K. 1994. Language as Social Semiotic: The Social Interpretation of Language and Meaning. New York: Routledge.

Kheirabadi, R. dan Moghaddam, S.B.A. 2012. "The Linguistic Representation of Iranian and Westren Actors of Iran's Nuclear Program in International Media: A CDA Study. Theory and Practice in Language Studies, Vol. 2, No. 10, pp 2183-2188, October 2012. Finland: Academy Publisher.

Ling Ip, J.Y. 2008. Analyzing Tourism Discourse: A Case Study of Hong Kong Travel Brochure. LCOM Papers Vol. 1 p. 1 - 19. Hongkong : the University of Hongkong.

Littosselti, L. 2010. Research Methods in Linguistics. London: Continuum International Publishing Group.

Mahsun. 2005. Metode Penelitian Bahasa. Tahapan Strategi, Metode dan Tekniknya. Jakarta: PT. Raja Grafindo Persada.

Mayr, A. 2008. Language and Power: An Introduction to Institutional Discourse. London: Continuum International Publishing Group.

Moleong, Lexy J. 2011. Metodologi Penelitian Kualitatif. Bandung: PT. Remaja Rosdakarya.

Nurudin. 2009. Pengantar Komunikasi Massa. Jakarta: PT. Rajagrafindo Perkasa.

Thurlow, C. And Jaworski, A. 2011. Tourism Discourse: Languages and Banal Globalization. Applied Linguistic Review.

Van Leeuwen, T. 2005. Introducing Social Semiotics. New York: Routledge. 
July 2017 Vol. 11. No. 2

Support DOAJ Directory Open Access Journal

http://ojs.unud.ac.id/index.php/eol

ISSN: 2442-7586 (Online)

Page: 93-104

ISSN: 2541-5514 (Print)

Van Leeuwen, T. dan Machin, D. 2007. Global Media Discourse: A Critical Introduction. New York: Routledge.

Van Leeuwen, T. 2008. Discourse and Practice. New Tools for Critical Discourse Analysis. Oxford-New York: Oxford University Press. 